\title{
Growth Promotion of Pepper Plants by Pantoea ananatis B1-9 and its Efficient Endophytic Colonization Capacity in Plant Tissues
}

\author{
Su-Nam Kim ${ }^{1,4 \#}$, Won Kyong Cho ${ }^{2 \sharp}$, Won-Il Kim ${ }^{1,3}$, Hyeong Jin Jee ${ }^{4}$ and Chang-Seuk Park ${ }^{1 *}$ \\ ${ }^{1}$ Department of Applied Biology \& Environmental Sciences, Gyeongsang National University, Jinju 660-701, Korea \\ ${ }^{2}$ Department of Agricultural Biotechnology, Seoul National University, Seoul 151-921, Korea \\ ${ }^{3}$ Microbial Safety Division, National Academy of Agricultural Science, Rural Development Administration (RDA), Suwon 441- \\ 707, Korea \\ ${ }^{4}$ Organic Agriculture Division, National Academy of Agricultural Science, Rural Development Administration (RDA), Suwon \\ 441-707, Korea
}

(Received on February 20, 2012; Revised on May 30, 2012; Accepted on June 20, 2012)

The bacteria B1-9 that was isolated from the rhizosphere of the green onion could promote growth of pepper, cucumber, tomato, and melon plants. In particular, pepper yield after B1-9 treatment on the seedling was increased about 3 times higher than that of control plants in a field experiment. Partial 16S rDNA sequences revealed that B1-9 belongs to the genus Pantoea ananatis. Pathogenecity tests showed non-pathogenic on kimchi cabbage, carrot, and onion. The functional characterization study demonstrated B1-9's ability to function in phosphate solubilization, sulfur oxidation, nitrogen fixation, and indole-3-acetic acid production. To trace colonization patterns of B1-9 in pepper plant tissues, we used DRAQ5 ${ }^{\text {TM }}$ fluorescent dye, which stains the DNAs of bacteria and plant cells. A large number of B1-9 cells were found on the surfaces of roots and stems as well as in guard cells. Furthermore, several colonized B1-9 cells resided in inner cortical plant cells. Treatment of rhizosphere regions with strain B1-9 can result in efficient colonization of plants and promote plant growth from the seedling to mature plant stage. In summary, strain B1-9 can be successfully applied in the pepper plantation because of its high colonization capacity in plant tissues, as well as properties that promote efficient plant growth.

Keywords : colonization, DRAQ5, endophytic, Pantoea ananatis, pepper, PGPR

The rhizosphere is the region of soil surrounding a plant root in which extensive biological and chemical activities are present (Walker et al., 2003) This area is primarily influenced by root exudates such as amino acids, organic acids, carbohydrates, sugars, vitamins, mucilage, and pro-

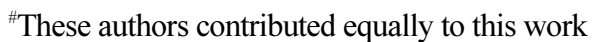

*Corresponding author.

Phone) +82-55-751-5442, FAX) +82-55-758-5110

E-mail)changpak@gnu.ac.kr
}

teins (Walker et al., 2003). Because of the high levels of nutrients in the rhizosphere, this zone is also the place where microbial communities preferentially interact (Barea et al., 2005). The bacteria highly enriched in the rhizosphere are known as rhizobacteria (Kloepper, 1995; Kloepper et al., 1991). Of these, the plant-growth-promoting rhizobacteria (PGPR) make up the most well-known group of beneficial rhizobacteria (Kloepper, 1995; Kloepper et al., 1991). PGPR are defined by 3 unique characteristics: ability to colonize the root, survival and high proliferation in competition with other microbes, and promotion of plant growth (Barea et al., 2005). The mechanisms through which PGPR promote plant growth, seed germination, and crop yield are not fully characterized. However, numerous studies have demonstrated that they have several abilities such as fixation of nitrogen (thereby increasing the supply of nitrogen), solubilization of inorganic phosphates by releasing organic compounds, and the release of siderophore, which provides iron to plant roots (Altomare et al., 1999; Bloemberg and Lugtenberg, 2001; Steenhoudt and Vanderleyden, 2000). In addition, they also produce several phytohormones including auxin, gibberellins, cytokinin, ethylene, and salicylic acid that have positive effects on host plants such as growth promotion and stress resistance (Ping and Boland, 2004). Furthermore, some Bacillus species have been reported to produce volatiles to promote plant growth and to elicite induced systemic resistance (Ryu et al., 2003; 2004).

A wide range of genera have been identified for PGPR including Pseudomonadaceae, Burkholderiaceae, and Enterobacteriaceae, which are most frequently observed (Ping and Boland, 2004; Weyens et al., 2009). Although numerous PGPR have been shown to promote growth of many plant species, their use in field treatments very often led to ineffective results (Thomashow, 1996). The main reason for such failures is the absence of precedent studies demonstrating PGPR colonization ability in plant tissues, especially 
in the rhizosphere (Compant et al., 2005). Moreover, such studies might be a good way to select endophytic bacteria that can efficiently colonize the internal tissue of the plant with no harmful effect on the host plant, as compared with epiphytic bacteria that reside on the surface of the roots (Compant et al., 2005; Cho et al., 2007; Ryan et al., 2008).

To evaluate colonization efficiency and density, it is necessary to establish a system that can trace the target strain in inoculated host plants. The introduction of antibiotic resistance genes into the bacteria is the simplest way to tag a selected bacterial strain. However, the bacteria can sometimes lose their antibiotic resistance (Wielbo and Skorupska, 2001). Therefore, a bacterial transposon system is currently commonly used to tag bacteria with green fluorescent protein (GFP) because of its specific insertion and stability in most gram-negative bacteria (Lambertsen et al., 2004; Sawabe et al., 2006). For example, colonization patterns of several endophytic PGPR have been shown using GFP marker, including Methylobacterium sp. in tomato and rice, Burkholderia sp. in grape, Rhizobium sp. and Burkholderia sp. in rice, Enterobacter sp. in poplar, Paenibacillus sp. in cucumber, and Pseudomonas sp. in olive (Compant et al., 2005; Poonguzhali et al., 2008; Prieto and Mercado-Blanco, 2008; Singh et al., 2009; Taghavi et al., 2009; Choi et al., 2004). In addition, a system containing the luciferase gene has been also applied to monitor colonization patterns of PGPR in the rhizosphere regions (Kim et al., 1998).

From the screening of bacterial strains to promote growth of pepper plants, strain B1-9 was selected as a promising strain of PGPR. B1-9 was identified as a Pantoea ananatis species. $P$. ananatis is a gram-negative bacterium belonging to the family Enterobacteriaceae and a well-known plant pathogen causing disease symptoms in various economically important crops worldwide, including both monocotyledons and dicotyledons (Coutinho and Venter, 2009). In particular, it causes center rot disease of onion, which is seed-borne and seed-transmitted in onion (Coutinho and Venter, 2009; Morohoshi et al., 2007). P. ananatis has also been reported to have ice nucleation activity that can be used in the food industry, as well as use a biological control for specific insect pests (Watanabe and Sato, 1999).

In this study, we investigated the ability of the newly identified, $P$. ananatis B1-9 to promote plant growth. Functional characterization of B1-9 related to plant growth promotion was performed. To confirm its successful application in the field, we investigated endophytic property, colonization pattern, and population density in plant tissues.

\section{Materials and Methods}

Isolation of rhizobacteria from plants. Various plants showing high growth promotion were collected from various regions (Kim et al., 2011). Root and rhizosphere samples were ground with pestle and mortar and diluted with $0.1 \mathrm{M} \mathrm{MgSO}_{4}$. Diluted samples were poured into $1 / 50$ Tryptic Soy Agar (TSA) medium. Individual colonies on TSA medium were selected based on colony morphology and color. Each isolate was cultured in liquid medium. Glycerol stocks were made by adding $20 \%$ glycerol to the bacterial cell culture. Glycerol stocks were kept at $-72{ }^{\circ} \mathrm{C}$.

Selection of bacteria that promote plant growth. Seedlings of pepper, tomato, and cucumber plants were grown in a greenhouse. After full expansion of foliage leaves in each plant, $50 \mathrm{~mL}$ cell suspensions of each bacterial isolate $\left(10^{8}\right.$ $\mathrm{cfu} / \mathrm{mL})$, as well as E. coli $\mathrm{DH} 5 \alpha\left(10^{8} \mathrm{cfu} / \mathrm{mL}\right)$ for use as a reference, were applied to the rhizospheres of plants. Two weeks after treatment with bacterial cells, plant growth promotion was evaluated by measuring plant height, plant fresh weight, and number of leaves.

Field experiments. Pepper seedlings grown in a commercial plug nursery greenhouse were transferred into the field. Thirty days after transfer, the rhizosphere region of each plant was treated with $100 \mathrm{~mL}$ of diluted bacterial culture $\left(10^{8} \mathrm{cfu} / \mathrm{mL}\right)$. After 60 days, the pepper fruit yield of plants treated with bacteria cells were compared with those of non-treated plants and plants treated with E. coli $\mathrm{DH} 5 \alpha$ control. A total of 25 pepper plants for each plot experiment were examined. In addition, 30-day-old melon (Cucumis melo) seedlings were transferred to the greenhouse. One week after plants were transferred, bacterial cells were placed in the rhizosphere regions of the melon plants. After 30 days of treatment, the total plant height and the number of leaves were examined. A total of 21 melon plants for each treatment were used in the field experiment.

DNA extraction, PCR amplification, cloning, and DNA sequencing. Crude genomic DNAs from bacterial isolates were prepared by boiling a small amount of cell material from colonies in $100 \mu \mathrm{L}$ of $5 \%$ Chelex 100 solution (BioRad; Richmond, USA) for $10 \mathrm{~min}$. After centrifugation at $12,000 \mathrm{~g}$ for $2 \mathrm{~min}$, the supernatant was used as the DNA template. The PCR reaction was performed using the eubacterial primers ( $27 \mathrm{f}$ and $1492 \mathrm{r}$ ) as previously described (Chernousova et al., 2008). The amplified partial 16S rDNA fragment was electrophoretically separated in $0.8 \%$ agarose gels. The target band was cut out and purified using a QIAquick ${ }^{\circledR}$ Gel Extraction Kit (QIAGEN; Hilden, Germany). The purified PCR product was cloned into the $p \mathrm{GEM}-\mathrm{T}$ Easy Vector (Promega; Madison, USA) following the manufacturer's instruction. Transformed plasmid in E. coli DH5 $\alpha$ competent cells was prepared for sequencing using the 
QIAprep Spin Miniprep Kit. Sequencing was done by Macrogen Co., Ltd. (Seoul, Korea). The retrieved 16S rDNA gene sequences were deposited in the nucleotide sequence database of the National Center for Biotechnology Information (NCBI) under accession number EF690403.

Phylogenetic analysis. The obtained partial 16S rDNA sequences of B1-9 were edited with the BioEdit program. BLAST was performed against the non-redundant nucleotide database in NCBI using obtained sequences as a query. To identify the genus of a bacterial isolate, the partial $16 \mathrm{~S}$ rDNA sequences of the target bacteria and closely related bacteria were aligned using the ClustalW program (Chenna et al., 2003). After editing sequences manually, the phylogenetic tree was constructed by the MEGA4.0 program using a neighbor-joining method (Tamura et al., 2007).

Pathogenicity of the identified $P$. ananatis B1-9. To determine pathogenecity of identified $P$. ananatis B1-9, the cultured bacterial cells with a concentration of $10^{8} \mathrm{cfu} / \mathrm{mL}$ diluted in $\mathrm{MgSO}_{4}$ buffer were applied onto Chinese cabbage, carrot, and onion. Bacterial cells were sprayed onto Chinese cabbage and were applied to the carrot and onion with a pipette. For comparison, a negative control without treatment and a positive control with Erwinia carotovora causing soft rot were also used.

Phosphate solubilization by selected bacteria. For the phosphate solubilization experiment, we prepared NBRIP (National Botanical Research Institute's Phosphate Growth) medium with $\mathrm{pH} 7.0$, which includes $10 \mathrm{~g}$ of glucose, $5 \mathrm{~g}$ of $\mathrm{Ca}_{3}\left(\mathrm{PO}_{4}\right)_{2}, 5 \mathrm{~g}$ of $\mathrm{MgCl}_{2} \cdot 6 \mathrm{H}_{2} \mathrm{O}, 0.25 \mathrm{~g}$ of $\mathrm{MgSO}_{4} \cdot 7 \mathrm{H}_{2} \mathrm{O}, 0.2$ $\mathrm{g}$ of $\mathrm{KCl}, 0.1 \mathrm{~g}$ of $\left(\mathrm{NH}_{4}\right)_{2} \cdot \mathrm{SO}_{4}$, and $15 \mathrm{~g}$ of agar for $1 \mathrm{~L}$. Bacterial cells were inoculated on NBRIP medium at $28^{\circ} \mathrm{C}$. Two days after treatment, the formation of a clear zone was observed.

IAA production by selected bacteria. In order to test the indole-3-acetic acid (IAA) production ability of selected bacteria, bacterial cells were grown in $5 \mathrm{~mL}$ of King $\mathrm{B}$ (KB) liquid medium supplemented with $0.1 \%$ of L-tryptophan (used as a precursor of IAA) at $28^{\circ} \mathrm{C}$ for $16 \mathrm{~h}$. Cultured cells were centrifuged at $8,000 \mathrm{rpm}$ for $30 \mathrm{~min}$. One volume of the supernatant was reacted with 2 volumes of Salkowski's medium containing $50 \mathrm{~mL}$ of $35 \% \mathrm{HClO}_{4}$ and $1 \mathrm{~mL}$ of $0.5 \mathrm{M} \mathrm{FeCl}_{3}$ for $30 \mathrm{~min}$ in dark conditions. After reaction, IAA production was determined by color change.

Sulfur oxidation. In order to test sulfur oxidation, a mineral salts medium prepared containing $5 \mathrm{~g}$ of $\mathrm{Na}_{2} \mathrm{~S}_{2} \mathrm{O}_{3}, 0.2 \mathrm{~g}$ of $\mathrm{K}_{2} \mathrm{HPO}_{4}, 2.5 \mathrm{~g}$ of $\mathrm{MgCl}_{2} \cdot 6 \mathrm{H}_{2} \mathrm{O}, 1 \mathrm{~g}$ of $\mathrm{NH}_{4} \mathrm{Cl}, 0.002 \mathrm{~g}$ of bromocresol purple ( $\mathrm{pH} 7.5$ ), and $150 \mathrm{mM}$ methanol for 1 L. Bacterial cells were inoculated onto the mineral salts medium and were cultured at $28^{\circ} \mathrm{C}$ for 2 days. Sulfur oxidation was evaluated by color change from purple to yellow.

Nitrogen fixation by selected bacteria. To test the nitrogen fixing ability of selected bacteria, a nitrogen-free semi-solid medium was prepared as described previously (Dobereiner et al., 1995). After treatment with nitrogenfixing bacteria, a characteristic "nodule" can be observed indicating nitrogen fixation.

Fluorescence labeling. In order to label $P$. ananatis B1-9, we used a mini-Tn7 system obtained from a previous study, which also showed stable insertion into the chromosome in various bacteria species. To make competent cells for transformation, $P$. ananatis B1-9 was grown in TSA medium. Subcultured cells were again grown in TSA medium at 28 ${ }^{\circ} \mathrm{C}$ until the optical density at $600 \mathrm{~nm}$ was $0.4-0.5$. The bacterial cells were centrifuged at $4,000 \mathrm{rpm}$ for $10 \mathrm{~min}$ at 4 ${ }^{\circ} \mathrm{C}$, and the pellets were washed 3 times with ice-cold $10 \%$ glycerol. Finally, the pellet was re-suspended with $500 \mu \mathrm{L}$ of ice-cold $10 \%$ glycerol. For transformation, the prepared competent cells were kept in ice, and the DNAs of the delivery plasmid and helper plasmid were added as described previously. The delivery plasmid includes GFP, as well as antibiotic-resistance genes, and the helper plasmid contains transposase genes (Lambertsen et al., 2004). After incubation in ice for $10 \mathrm{~min}$, the mixture was electroporated using a Gene Pulser Plus (Bio-Rad) with settings of $2.5 \mathrm{kV}$, $200 \Omega$ and $25 \mu \mathrm{F}$. Transformed cells were selected on Luria-Bertani (LB) medium containing chloroamphenicol antibiotic $(25 \mathrm{mg} / \mathrm{mL})$. To select positive transformants, colony PCR was performed using GFP (478) and Tn7GlmS primers as described previously (Lambertsen et al., 2004).

Examination of the colonization density and pattern of B1-9 in pepper seedlings in gnotobiotic condition. To check the density of bacterial cells in pepper plant tissues, pepper seeds were first sterilized with $1 \% \mathrm{NaOCl}$ and $70 \%$ EtOH. The seeds were placed on a square plastic growth box containing $1.2 \%$ agar supplemented with MS medium. Pepper plants were grown at $25^{\circ} \mathrm{C}$ with a light and dark $(16$ $\mathrm{h} / 8 \mathrm{~h}$ ) photoperiod. Bacterial cells were grown at $28^{\circ} \mathrm{C}$ for $16 \mathrm{~h}$. After centrifugation, bacterial cells were diluted with phosphate-buffered saline (PBS; pH 6.5) buffer. The diluted cells $\left(10^{8} \mathrm{cfu} / \mathrm{mL}\right)$ were applied to the rhizosphere regions of plants with full expansion of foliage leaves. Seven days after treatment, colonization density and patterns of B1-9 in pepper roots were observed. 
Observation of bacterial cells in pepper plant tissues. Inoculated plants were taken from the MS agar. Plants were gently washed with sterilized water to remove agar pieces on the root. Then, plants were sectioned into 3 parts: roots, stems, and leaves. Samples, supplemented with $10 \mathrm{~mL}$ of PBS buffer, were ground by mortar and pestle. The homogenized samples were then vortexed for $30 \mathrm{~s}$. Samples were again diluted serially 10 times and were sprayed on LB medium containing chloroamphenicol $(25 \mathrm{mg} / \mathrm{mL})$. After 2 days of incubation at $28^{\circ} \mathrm{C}$, bacterial colonies were counted. Values were obtained from 3 replications.

Calculation of the number of endophytic bacteria. To calculate the endophytic bacterial cell density in pepper plant tissues, the inoculated plants were first divided into 3 parts: roots, stems, and leaves. Then each sample was surface sterilized for $10 \mathrm{~min}$ using $1 \% \mathrm{NaOCl}$. Samples were again washed with $70 \% \mathrm{EtOH}$ followed by sterilized distilled water. Surface-sterilized samples supplemented with $10 \mathrm{~mL}$ of PBS buffer were ground by mortar and pestle. Vortexing, dilution, incubation of cells, and counting of colonies were performed as described above. The number of epiphytic bacterial cells was calculated by subtracting the number of endophytic bacterial cells treated with surface sterilization from the total number of bacterial cells without surface sterilization.
Labeling bacterial cells with DRAQ5 ${ }^{\mathrm{TM}}$ fluorescence dye and confocal microscopy. To observe the colonization pattern of B1-9 in pepper plants, a culture of B1-9 was inoculated into pepper plants showing foliage leaves grown on MS medium. After 1 week of treatment, pepper plants were washed with PBS buffer and stained with DRAQ5TM (final concentration $10 \mu \mathrm{M}$ in PBS buffer) for $30 \mathrm{~min}$. There was no washing step. DRAQ5 ${ }^{\mathrm{TM}}$ is a novel far-red fluorescent DNA dye that normally stains nuclei and chloroplasts in plant tissues (Biostatus Limited; Leicestershire, UK). Red fluorescence imaging was obtained using an Olympus (Tokyo, Japan) FV1000 confocal microscope with excitation at $633 \mathrm{~nm}$ and emission at $665 \mathrm{~nm}$.

Statistical analysis. Statistical analysis was performed by the analysis of variance (ANOVA) protected the least significant difference (LSD) test using the Statistical Analysis System (SAS) computer program version 9.3 (http://www.sas.com/).

\section{Results}

Selection of growth promoting rhizobacteria. We selected the strain B1-9, which was previously identified to promote growth of cucumber plants (Kim et al., 2011). To test the ability of B1-9 to increase plant growth, we
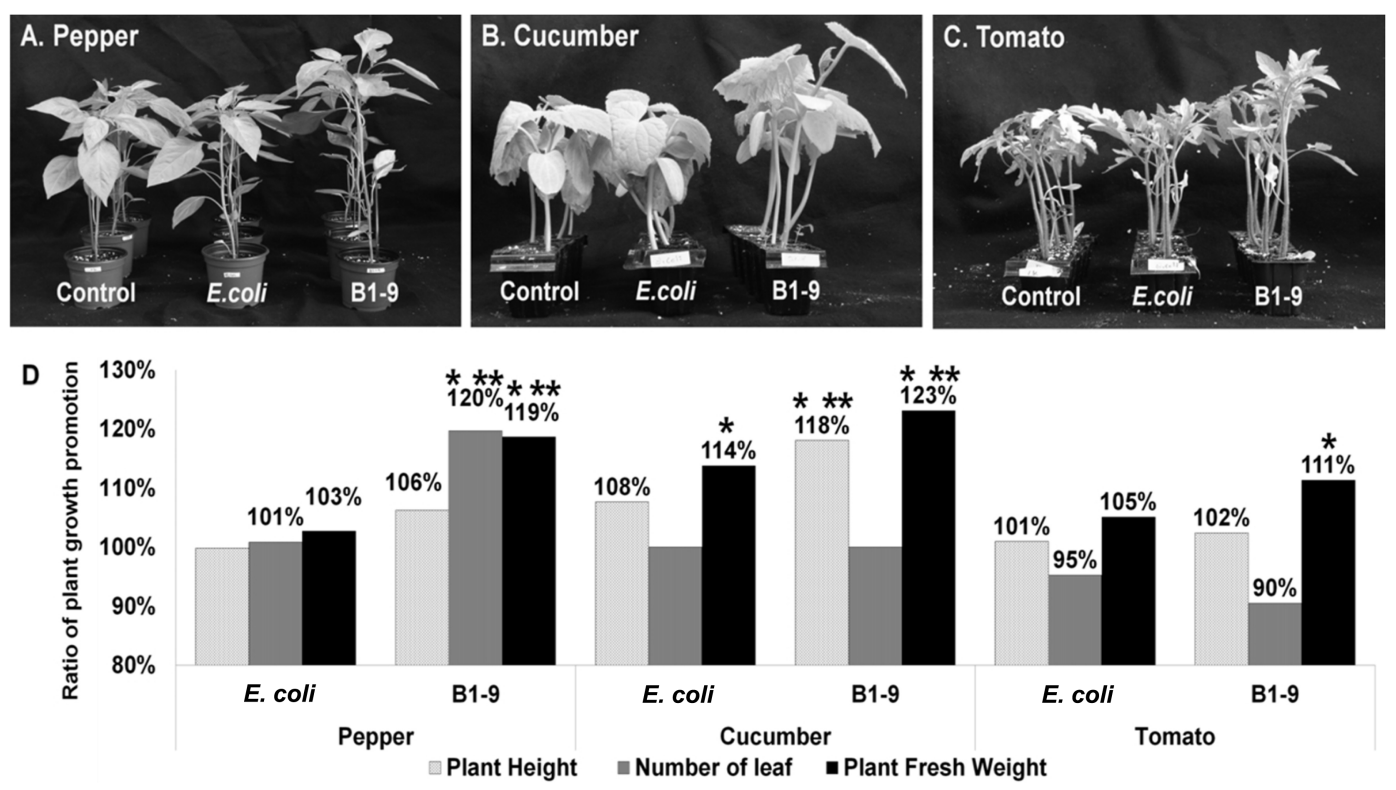

Fig. 1. Plant growth enhancement of pepper, cucumber, and tomato by Pantoea ananatis B1-9. Cultured P. ananatis B1-9 cells were applied onto the rhizosphere regions of 3 kinds of plants: pepper (A), cucumber (B), and tomato (C). Two weeks after treatment, growth of plants treated with $P$. ananatis B1-9 was compared with that of plants without treatment (control) and plants treated with $E$. coli DH5 $\alpha$ (non-effective bacteria). (D) At 14 days after treatment of $P$. ananatis B1-9 to the root zone of plants, we measured 3 parameters of plant growth: plant height, number of leaves, and plant fresh weight. Untreated plants were used as references. Each ratio was obtained by comparing reference plants. Bars without any value indicate $100 \%$ value which is identical to those of reference plants. ${ }^{*}$ and $* *$ indicate significant differences at 0.05 and 0.01 levels, respectively, as compared to references. 
performed experiments with 3 plant species: pepper, cucumber, and tomato. As compared with control plants, plants treated with the B1-9 strain showed enhancement of growth in all 3 species (Fig. 1A-C). For example, for plant height, B1-9 was most effective on cucumber plants, which showed an $18 \%$ increase in height compared with untreated cucumber plants (Fig. 1D). The plant fresh weight increased in all 3 plant species after treatment with B1-9. For instance, weight increases in pepper and cucumber plants were 19\% and $23 \%$, respectively, as compared with untreated plants. B1-9 was effective at increasing leaf growth only on pepper plants with a $20 \%$ increase in the number of leaves as compared with control plants (Fig. 1D). To prove reliability of the experiments, we performed ANOVA test demonstrating plant growth promotion by B1-9. Especially, ANOVA test strongly supported growth promotion of pepper and cucumber plants by B1-9. On the basis of results for all 3 growth parameters, we determined that B1-9 was most efficient in pepper plants, in which it caused strong enhancement of all 3 parameters of plant growth.

Evaluation of plant growth promotion in the field. As shown above, strain B1-9 was highly effective in growth promotion of the seedling stage of pepper plants. To evaluate the plant growth promotion effect in the field, experiments were conducted on pepper and melon plants grown in the field. After treatment with B1-9, pepper fruit yield was highly increased, as shown in Fig. 2A-C. For instance, 30 days after treatment, the total pepper yield was $8.1 \mathrm{~kg}$, which is 3 times higher than that of untreated plants (Table 1). The efficiency of plant growth promotion was stable even at 60 days after treatment, showing $18.6 \mathrm{~kg}$ of pepper fruit yield, which is 2.86 times higher than that of untreated plants (Table 1). ANOVA test supported yield difference between B1-9 and control. Treatment with B1-9 also increased the growth of melon plants in the field, as measured by total height and number of leaves and this results were supported by ANOVA test (Fig. 2D).

Identification of strain B1-9 based on partial 16S rDNA sequences. In order to identify strain B1-9, the partial 16S
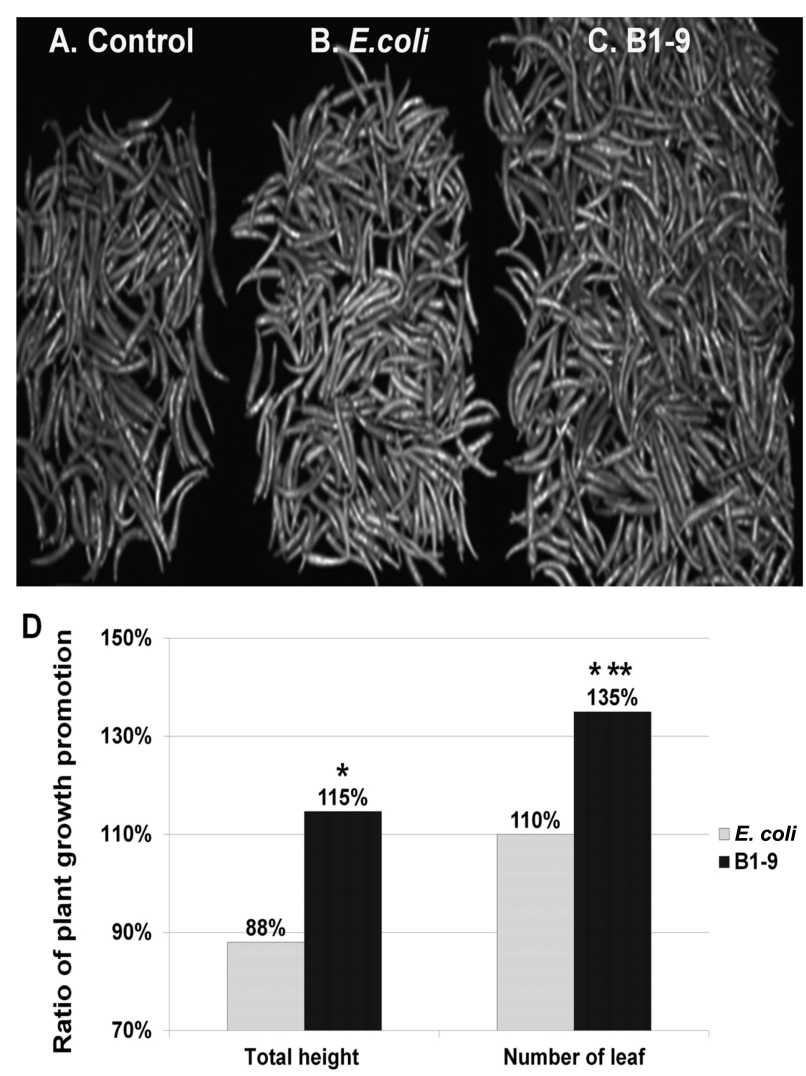

Fig. 2. Increased yield of green pepper fruit in a field experiment. At 60 days after treatment, the pepper fruit yields of plants treated with Pantoea ananatis B1-9 bacteria cells (C) were compared with those of plants treated with $E$. coli $\mathrm{DH} 5 \alpha(\mathrm{B})$ and untreated plants as a control (A). (D) Growth promotion of melon (Cucumis melo) plants by Pantoea ananatis B1-9 in field experiments. After treatment with B1-9, the total height and number of leaves in melon plants were examined and compared to those of untreated melon plants. $*$ and $* *$ indicate significant differences at 0.05 and 0.01 levels, respectively, as compared to untreated plants.

rDNA sequences of B1-9 were amplified by PCR and sequenced. The BLAST results, as well as a created phylogenetic tree, revealed that the strain belongs to genus Pantoea and is closely related to P. ananatis (Fig. 3). P. ananatis B1-9 is gram-negative, rod-shaped, and yellow in

Table 1. Enhancement pepper fruit yield by Pantoea ananatis B1-9 in field experiments. The total weight of pepper fruits harvested from 25 plants was examined twice. These examinations were performed at 30 days and 60 days after bacterial treatment. * and ** indicate significant differences at 0.05 and 0.01 levels, respectively, as compared to control

\begin{tabular}{|c|c|c|c|c|c|}
\hline \multicolumn{3}{|c|}{ First examination } & \multicolumn{3}{|c|}{ Second examination } \\
\hline Treatment & Total yield $(\mathrm{Kg})$ & Average yield (g) & Treatment & Total yield $(\mathrm{Kg})$ & Average yield (g) \\
\hline Control & 2.7 & $135 \pm 13.27$ & Control & 6.5 & $325 \pm 30.31$ \\
\hline E. coli $\mathrm{DH} 5 \alpha$ & $3.6^{*}$ & $180 \pm 15.97^{*}$ & E. coli $\mathrm{DH} 5 \alpha$ & 6.8 & $340 \pm 31.69$ \\
\hline P. ananatis B1-9 & $8.1 * *$ & $405 \pm 33.97 * *$ & B1-9 & $18.6^{* *}$ & $930 \pm 163.41 * *$ \\
\hline
\end{tabular}




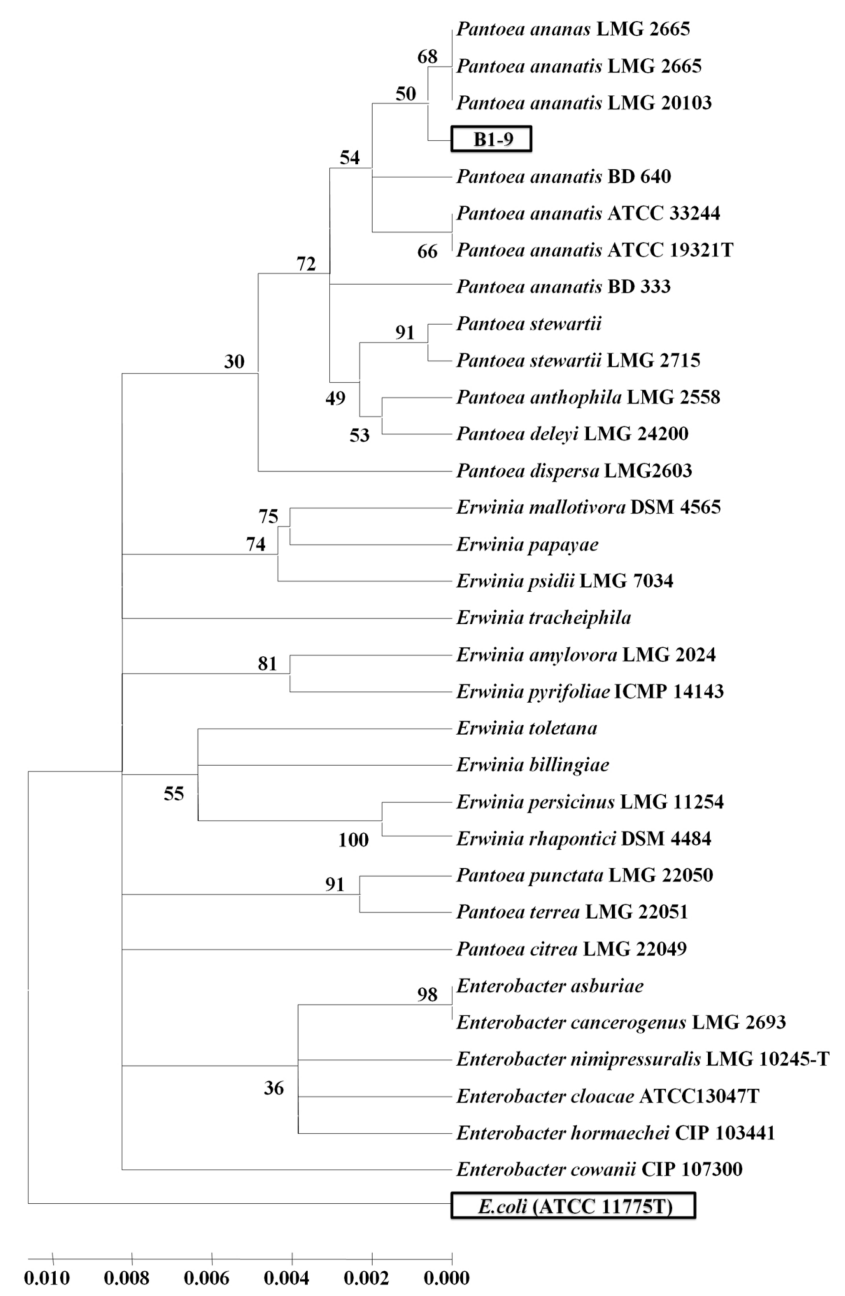

Fig. 3. Identification of B1-9 by partial $16 \mathrm{~S}$ rDNA sequences and phylogenetic analysis. 16S rDNA sequences of B1-9 and closely related bacteria strains were used for the construction of a phylogenetic tree. The tree was constructed by using MEGA4 after aligning the sequences with clustalW and generating an evolutionary distance matrix inferred by the neighbor-joining method using the Kimura parameter. The numbers at the nodes indicate the levels of bootstrap support based on data for 1,000 replicates; only values inferred greater than $50 \%$ are presented. The scale bar indicates 0.01 substitutions per nucleotide position.

color. It grows optimally at $25^{\circ} \mathrm{C}-30^{\circ} \mathrm{C}$. Therefore, the strain was named $P$. ananatis $\mathrm{B} 1-9$.

Pathogenicity of $\boldsymbol{P}$. ananatis B1-9. The pathogenicity of $P$. ananatis B1-9 was tested using Chinese cabbage, carrot, and onion. Erwinia carotovora, which is known to cause soft rot, was used as a positive control (Fig. 4). After treatment with Erwinia carotovora, all 3 plants showed typical soft rot symptoms; however, plants treated with B1-9 did not show any significant symptoms, thus indicating that the newly identified $P$. ananatis B1-9 is non-pathogenic against Chinese cabbage, carrot, and onion (Fig. 4).

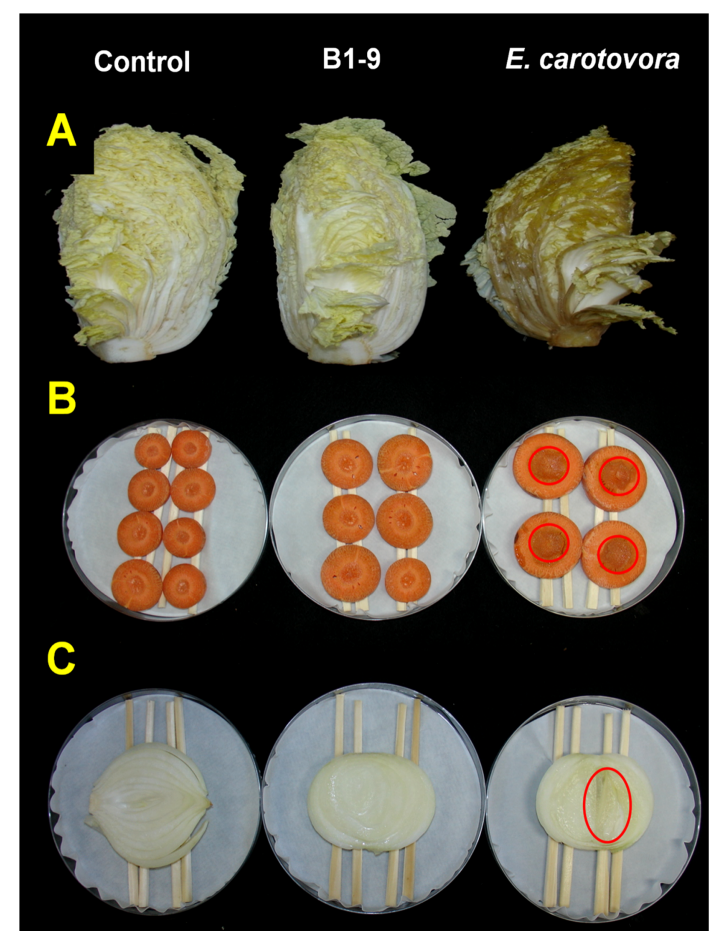

Fig. 4. Symptom development after inoculation of Pantoea ananatis B1-9 to Chinese cabbage, carrot, and onion. To determine pathogenecity of $P$. ananatis B1-9, the cultured bacterial cells were inoculated onto Chinese cabbage, carrot, and onion. For comparison, a negative control without treatment and a positive control with Erwinia carotovora causing soft rot were also used. The red circles indicate the regions infected by $E$. carotovora.

Functional characterization of $\boldsymbol{P}$. ananatis B1-9. To investigate functional characteristics of $P$. ananatis B1-9 as a PGPR, several experiments were conducted, including tests of phosphate solubilization, sulfur oxidation, nitrogen fixation, and IAA production. After treatment of B1-9 on a medium containing tricalcium phosphate, the inoculated regions gradually changed into clear round zones indicating the production of phosphatase enzymes by B1-9 (Fig. 5A). Treatment of B1-9 in the medium for sulfur oxidation test induced a yellow-colored zone in the inoculated regions (Fig. 5B). The addition of B1-9 to the nitrogen-free $\mathrm{NFb}$ medium changed the color of the medium from green to blue with a characteristic pellicle formation. This result indicates that B1-9 has an ability to fix nitrogen (Fig. 5C). To check IAA production, we conducted a colorimetric assay using an L-tryptophan precursor. Addition of cultured B1-9 into the medium altered the color from orange to red, indicating IAA production by B1-9 (Fig. 5D).

Transformation of B1-9 for antibiotic resistance and GFP tagging. In order to study colonization patterns of B19 in pepper plant tissues, GFP tagging of the B1-9 cells was 


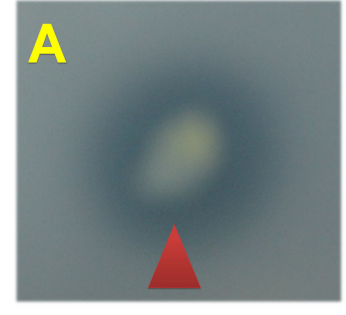

Phosphate solubilization

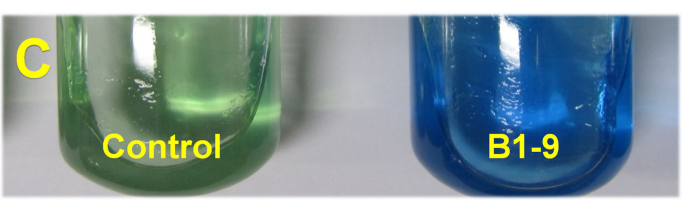

Nitrogen fixation

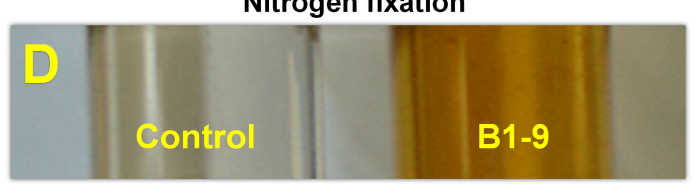

IAA production

Fig. 5. Characteristics of Pantoea ananatis B1-9 in relation to plant growth promotion. P. ananatis B1-9 has functions for (A) phosphate solubilization, (B) sulfur oxidation, (C) nitrogen fixation, and (D) IAA production.

performed using a mini $\mathrm{Tn} 7$ system (Lambertsen et al., 2004). Delivery plasmid and helper plasmid were transformed into competent B1-9 cells by electroporation. The transformed cells were grown in LB medium containing chloroamphenicol. The positive colonies were selected by colony PCR. Several colonies that were resistant to antibiotics were obtained. To check for insertion of the transposon, colony PCR was performed several times with changing PCR conditions and primers. However, only an unspecific band about $3 \mathrm{kbp}$ in size was amplified. As a control, a Pseudomonas species known to be successful with a mini $\operatorname{Tn} 7$ system was used (Lambertsen et al., 2004). It is interesting to note that positive colonies were obtained from Pseudomonas species by colony PCR, and they also showed GFP activity under UV light. Finally, we found that

Table 2. The number of Pantoea ananatis B1-9 bacterial cells colonized in plant tissues

\begin{tabular}{cccc}
\hline \hline Tissue & Epiphytic & Endophytic & Total \\
\hline Roots & $1.5 \times 10^{7}$ & $2.6 \times 10^{6}$ & $1.8 \times 10^{7}$ \\
Stems* & $1.4 \times 10^{7}$ & $1.9 \times 10^{6}$ & $1.5 \times 10^{7}$ \\
Leaves $^{* * * *}$ & $2.0 \times 10^{6}$ & $4.6 \times 10^{5}$ & $2.4 \times 10^{6}$
\end{tabular}

The numbers of bacterial cells present in $1 \mathrm{~g}$ tissue samples from the roots, stems, and leaves of pepper plants were examined. The number of epiphytic bacterial cells was obtained by subtracting the number of endophytic bacteria from the number of total bacteria cells. * and ** indicate significant differences at 0.05 and 0.01 levels, respectively, as compared to roots. the transformed B1-9 cells contain only plasmids with antibiotic resistances but do not express GFP because of the absence of an att $\operatorname{Tn} 7$ site in P. ananatis B1-9.

Colonization density of $P$. ananatis B1-9 in pepper plant tissues. To calculate the number of B1-9 cells in plant tissues, cultured cells were inoculated on the rhizosphere regions of 25-day-old pepper plants grown in aseptic conditions. One week after treatment, the numbers of epiphytic and endophytic bacterial cells were calculated. A large number of bacterial cells were found in the roots, followed by the stems and leaves (Table 2). For example, about $1.5 \times$ $10^{7} \mathrm{cfu} / \mathrm{g}$ were detected in the surface root tissues, whereas $2.6 \times 10^{6} \mathrm{cfu} / \mathrm{g}$ were present in the inner root tissues (Table 2 ). In addition, a similar number of cells was present in the stems, $1.4 \times 10^{6} \mathrm{cfu} / \mathrm{g}$ epiphytically and $1.9 \times 10^{6} \mathrm{cfu} / \mathrm{g}$ endophytically (Table 2 ).

Observation of red fluorescence of nuclear and chloro-

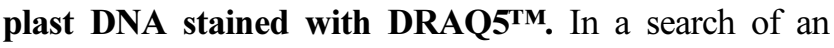
alternative way to trace B1-9's colonization patterns, we found a red fluorescence dye called DRAQ5 ${ }^{\mathrm{TM}}$. In general, DRAQ5 $^{\text {TM }}$ can stain DNA specifically (Martin et al., 2005). As shown in Fig. 6A-C, plant tissues stained with DRAQ5 ${ }^{\mathrm{TM}}$ showed red fluorescence in the nuclei and chloroplasts. In the mesophyll and endodermal cells of plant leaves, the stained tissues showed clearly the localization of chloroplasts with red fluorescence (Figs. 6A and $6 \mathrm{~B})$. In addition, the root tissues stained with DRAQ5 ${ }^{\mathrm{TM}}$ showed nuclear localization with red color (Fig. 6C).

Epiphytic colonization pattern of $P$. ananatis B1-9 in pepper plant tissues. One week after bacterial treatment, pepper plants were sampled and divided into 3 parts: roots, stems, and leaves. Each plant tissue was again split into small pieces and stained with DRAQ5 ${ }^{\mathrm{TM}}$ for Confocal laser scanning microscopy (CLSM). In general, high red fluorescence was observed from root samples, followed by stems and leaves. Numerous cells were colonized in the surface of the lateral roots, root hairs, root tips, and primary roots (data not shown). Bacterial cells were more frequently found in the lateral roots and root hairs than in the root tips and primary roots (data not shown). To get good images, root hairs were used for CLSM. Single rod cells were sporadically distributed in the surface of root tissue and circularshaped bacterial cells were accumulated into clusters (Fig. 6D). Bacterial cells were very often present along the surface of the epidermal cell layers in the shape of long linear strings (Fig. 6E). Sometimes, a large number of bacterial cells were clustered together (Fig. 6F). Such clusters were detected throughout the entire roots. The magnified image shows clearly a large number of cells colonized on 

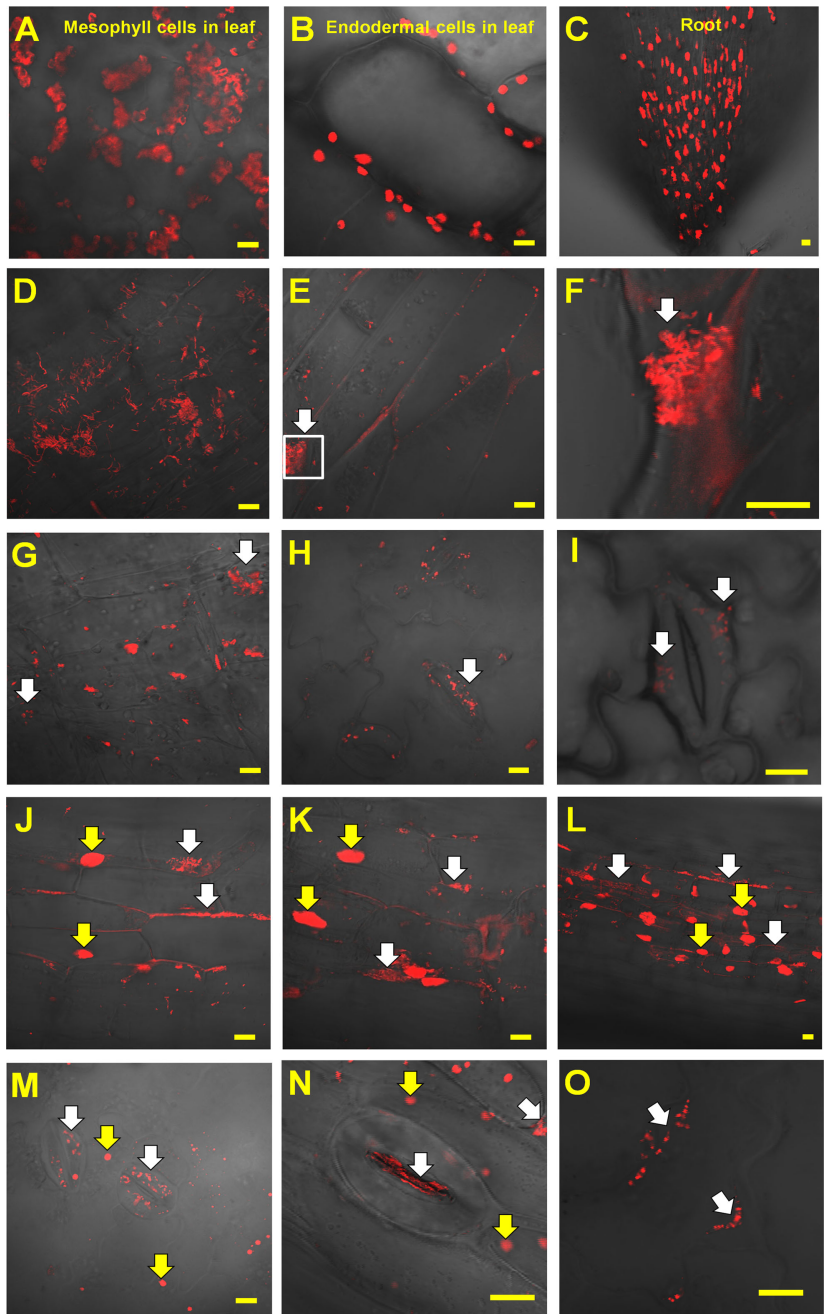

Fig. 6. Red fluorescence images stained with DRAQ5 ${ }^{\mathrm{TM}}$ fluorescent dye in pepper plant tissues (A-C). DRAQ5TM is a novel far-red fluorescent DNA dye that normally stains nuclei and chloroplasts in plant tissues. Epiphytic colonization patterns of Pantoea ananatis B1-9 in pepper plant tissues (D-I). Inoculated plant tissues were stained with DRAQ5 ${ }^{\mathrm{TM}}$ for $10 \mathrm{~min}$. Yellow arrows indicate nuclear DNA of host plant, and white arrows indicate stained bacteria. P. ananatis B1-9 cells were found in root tissues (D-F), stems (G), and leaves (H and I). Endophytic colonization patterns of $P$. anantis B1-9 in pepper plant tissues (J-O). Inoculated plant tissues were stained with DRAQ5 ${ }^{\mathrm{TM}}$ for $10 \mathrm{~min}$. Yellow arrows indicate the nuclear DNA of the host plant, and white arrows indicate stained bacteria. $P$. ananatis B1-9 cells were found in root tissues (J-L), stems (M and $\mathrm{N}$ ), and leaves $(\mathrm{O})$. Scale bar is $10 \mu \mathrm{m}$.

the surface of root hairs (Fig. 6F). In addition, many cells could be detected on the surface of stems (Fig. 6G). The colonization pattern of bacterial cells on the surface of stem is similar to that in the roots, showing an unequal distribution of numerous cells (Fig. 6G). Similarly, numerous single cells and clusters of bacterial cells could be detected in whole stems. Bacterial cells with red fluorescence were detected on all parts of the leaves. In particular, aggregated bacterial cells were frequently found on the surface of leaf tissues in the vicinity of stomata of the adaxial surfaces (Figs. 6H and 6I). Furthermore, bacterial cells also colonized the surface of trichomes in leaves and stems (data not shown).

Endophytic colonization pattern of $P$. ananatis B1-9 in pepper plant tissues. Under observation with a CLSM, red-fluorescence-labeled bacterial cells were found in most parts of the inner plant tissues. For example, bacterial cells were highly present along the cortical cell layers of root tissues (Figs. 6J and 6K). Yellow arrows in Fig. 6J-N indicate nuclei in host plant tissues with round shapes showing red fluorescence as well. Although DRAQ5 ${ }^{\mathrm{TM}}$ stains nuclear DNA of both plants and bacteria, the nuclei in plant tissues are easily distinguishable from those of bacterial cells by size and shape. The clustered bacterial cells or numerous single cells were colonized in the intercellular spaces of the rhizodermal cells. A large number of bacterial cells were also colonized in the cell walls of the inner root tissues, mostly cortical cells (Fig. 6L). In stem tissues, there are numerous chloroplasts that are also stained with DRAQ5 ${ }^{\mathrm{TM}}$. Yellow arrows indicate chloroplasts with a red fluorescence in stems (Figs. $6 \mathrm{M}$ and $6 \mathrm{~N}$ ). In addition, several bacterial cells with high red fluorescence were detected in the mesophyll cells and inner spaces of leaves (data not shown). There were many clumps of cells in the vicinity of guard cells and cortical cells in the pepper stems (Figs. 6M and $6 \mathrm{~N}$ ). Interestingly, groups of bacterial cells were detected in stomata penetrating into the inner cells of the stems (Fig. $6 \mathrm{~N}$ ). Such bacteria in stomata chambers were frequently found in pepper stems and leaves. To check for bacterial cells within vascular bundles, transverse sections of pepper stems were prepared after surface sterilization. No single cells were found within the vascular tissues. However, several individual cells were present in cortical cells that are located close to vascular bundles. Numerous bacterial cells were colonized along the epidermal cell layer of the leaves, forming clusters (Fig. 6O). As a result, the colonization pattern of $P$. ananatis B1-9 in pepper plants was successfully traced with the DRAQ5 ${ }^{\mathrm{TM}}$ fluorescent dye.

\section{Discussion}

In this study, newly identified B1-9 bacteria - isolated from the rhizosphere region of green onion plants in South Korea in 2004 - promoted the growth of pepper, cucumber, and tomato seedlings. Among the 3 tested plant species, pepper plants showed the strongest response to B1-9. Pepper plants (Capsicum annuum L.) are cultivated worldwide. 
Red peppers, in particular, are economically very important, with a high consumption in Korea as a primary ingredient in Kimchi, a favorite Korean food. So far, several rhizobacteria have been reported to promote plant growth of peppers; these include the genera Bacillus, Pseudomonas, and Pantoea (Domenech et al., 2006; Joo et al., 2004; Kang et al., 2007; Lucas Garciìa et al., 2004). The pepper-growthpromoting Bacillus species have been identified as producing gibberellins (Joo et al., 2005) which are kinds of phytohormones involved in several biological processes in plants, including seed germination, stem elongation, and flowering (Hedden and Kamiya, 1997). In addition, Pseudomonas and Pantoea species have been shown to function in pepper plant growth and systemic resistance against $X$. axonopodis pv. Vesicatoria. (Kang et al., 2007). Interestingly, strain B1-9 in this study is very similar to the strain PS27 studied previously (Kang et al., 2007). Both of these were revealed as $P$. ananatis by partial $16 \mathrm{~S}$ rDNA sequences and are endophytic bacteria with high growth promotion of pepper plants. It might be interesting to compare the 2 strains by means of $16 \mathrm{~S}$ rDNA sequences and PGPR abilities. For that, we tried to get the strain PS27 from other group; however, it seems that they lost the stock recently. Therefore, the direct comparison was impossible. According to previous research, root fresh weight was significantly increased by the strain PS27 as compared with other growth parameters; this suggests that root growth is an important point in pepper cultivation (Kang et al., 2007). In addition, as shown in this study, $P$. ananatis can promote growth of other plant species. For instance, B1-9 enhanced growth promotion in cucumber, tomato, and melon plants. Moreover, previous studies reported that $P$. ananatis was isolated as an endophytic PGPR from ginseng, papaya, and maize (Cho et al., 2007; Rijavec et al., 2007; Thomas et al., 2007).

This study shows, for the first time, the successful treatment of pepper plants with newly identified $P$. ananatis B1-9 leading to an increased pepper fruit yield. In particular, pepper fruit yield in plants treated with B1-9 was 3 times higher than that of control pepper plants in the field. Although many previous reports have shown plant growth promotion, they often failed to examine essential growth parameters. It is likely that increased fresh weight is highly correlated with high fruit yield. High fruit yield is the most striking point in this study, suggesting that B1-9 can be successfully used in pepper cultivation.

$P$. ananatis is a gram-negative bacterium belonging to the family Enterobacteriaceae and is a well-known plant pathogen causing disease symptoms in various economically important crops including both monocotyledons and dicotyledons worldwide (Coutinho and Venter, 2009). In particular, it causes center rot disease of onions and is seed- borne and seed-transmitted in onion (Coutinho and Venter, 2009; Morohoshi et al., 2007). P. ananatis is also reported to have ice nucleation activity that can be used in the food industry, as well as biological control of specific insect pests (Watanabe and Sato, 1999). For our pathogenicity experiments, an Erwinia carotovora species phylogenetically close to B1-9 that causes soft rot was used as a control (Toth et al., 2003). The B1-9 strain did not cause any disease symptoms in the Chinese cabbage, carrot, and onion plants, confirming that B1-9 is a non-pathogenic bacterium against at least three plants that is completely different from known pathogenic $P$. ananatis species that cause disease in onion plants. In addition, a recent study provides a draft genome sequence for $P$. ananatis B1-9 suggesting that B1-9 does not possess genes associated with pathogenesis but genes related to plant growth promotion (Kim et al., 2012).

$P$. ananatis has been shown to produce IAA, which is a member of auxin family (Enya et al., 2007; Halda-Alija, 2003). Auxins are widely used for commercial purposes in horticulture, such as the promotion of flowering and fruit set and the prevention of fruit drop (Benjamins and Scheres, 2008). Thus, IAA production by B1-9 is a major factor in the enhancement of plant growth and fruit yield in pepper plants. Functional characterization of B1-9 was performed, showing that B1-9 can also function in phosphate solubilization, sulfur oxidation, and nitrogen fixation. Although several abilities influenced by B1-9 were characterized in this study, it is likely that not 1 single mechanism but rather all of the identified mechanisms play important roles for positive growth response of plants.

Many studies have reported the inconsistent effect of PGPR between pot and field experiments (Thomashow, 1996; Compant et al., 2005). The main reason for this discrepancy might the colonization ability of studied bacterial strains in the field (Compant et al., 2005). Therefore, it is necessary to study colonization pattern, plant growth, and yield. To observe the colonization pattern of B1-9, we used DRAQ5 ${ }^{\mathrm{TM}}$ fluorescence dye, which stains the DNA of bacteria and plant cells. A large number of B1-9 cells were found in the surfaces of roots and stems, as well as in guard cells. Furthermore, several colonized B1-9 cells resided in inner cortical cells. Therefore, treatment of B1-9 in rhizosphere regions can lead to efficient colonization in the plants and promote plant growth from seedling to mature plant stage. Previously, the epiphytic and endophytic colonization of $P$. ananatis have been shown in tomato leaves (Enya et al., 2007). That study found that bacterial population size increased as plant leaves became bigger (Enya et al., 2007). As a result, the bacterial cells present within and on the surfaces of leaves produce IAA that is able to enhance plant growth as well as fruit yield. 
To observe colonization patterns of B1-9 in pepper plant tissues, GFP tagging of B1-9 cells was conducted using a mini Tn7 system. After transformation of plasmids into B19 competent cells, antibiotic resistant colonies were obtained. However, bacterial cells containing the target transposon including GFP and antibiotic resistances were not obtained from B1-9 cells. In contrast, GFP tagging was successful with genus Pseudomonas used as a positive control. It seems that B1-9 does not contain an att $\operatorname{Tn} 7$ site in the chromosome. Therefore, GFP tagging failed in B1-9 cells. Previous studies also showed that 2 bacteria strains belonging to Pseudomonas putida did not contain attTn7 sites, causing no GFP expression (Staley et al., 1997).

Generally, in the field of research related to PGPR, GFP or GUS tagging methods and fluorescence microscopy have been widely used to visualize bacterial cells (Bloemberg, 2007). In addition, scanning electronic microscopy (SEM) has also been used to trace bacterial colonization in plant tissues (Ugoji et al., 2005). In a search of an alternative way to trace bacterial colonization, we found a red fluorescent dye called DRAQ5 ${ }^{\mathrm{TM}}$, which stains the DNA of bacterial cells and the DNA of nuclei and chloroplasts in plant tissues.

So far, only a limited number of studies have applied DRAQ5 ${ }^{\mathrm{TM}}$, mostly in animal cells. However, DRAQ5 ${ }^{\mathrm{TM}}$ was used as a fluorescent dye to stain the nuclear DNA of root hairs in Arabidopsis plants and to examine the physiological conditions of microorganisms during fermentation processes (Da Costa et al., 2006; Herrero et al., 2006). As compared with other fluorescent DNA dyes, it has many advantages, such as a low level of photobleaching and a wide range of red excitation/emission ranges that is compatible with other fluorescent proteins including GFP, cyan fluorescent protein, and yellow fluorescent protein (Martin et al., 2005). Also, it does not take a long time to stain samples (1-5 min). For the simultaneous study of the colonization patterns of 2 different PGPR strains in the rhizospheres of plants, DRAQ5 ${ }^{\mathrm{TM}}$ can easily combine with other fluorescens such as GFP-tagged bacteria. Merged images will provide clearly distribution patterns of the 2 bacteria in the plant tissues. The most striking merit of DRAQ5 ${ }^{\mathrm{TM}}$ is that it can easily stain gram-positive bacteria, with which transformation of plasmids is normally difficult. Although previous research has shown that diverse grampositive bacteria can be transformed via electroporation, it still remains difficult (Dubnau, 1999; Wirth et al., 1989). Although DRAQ5 ${ }^{\mathrm{TM}}$ is very useful dye for the fluorescence study, it also has disadvantages, including high toxicity to humans and lack of specificity for target bacteria. Therefore, it is necessary to grow plants in aseptic conditions to observe colonization patterns of interesting bacteria. The present study is the first report in which DRAQ5 ${ }^{\mathrm{TM}}$ was applied for the study of colonization patterns of PGPR in plant tissues.

In conclusion, the newly identified $P$. anantis B1-9 can promote growth of several plant species, in particular, pepper plants with the increased fruit yield. Furthermore, the strain B1-9 can be successfully applied because of its high colonization capacity in plant tissues and abilities to function in phosphate solubilization, sulfur oxidation, nitrogen fixation, and IAA production.

\section{Acknowledgements}

This work was supported by the National Research Foundation of Korea (NRF) grant funded by the Korea government (MEST) (No. 2011-0010027) and a grant from the Next-Generation BioGreen 21 Program (No. PJ00798402), Rural Development Administration, Republic of Korea.

\section{References}

Altomare, C., Norvell, W. A., Bjorkman, T. and Harman, G. E. 1999. Solubilization of phosphates and micronutrients by the plant-growth-promoting and biocontrol fungus trichoderma harzianum rifai 1295-22. Appl. Environ. Microbiol. 65:29262933.

Barea, J. M., Pozo, M. J., Azcon, R. and Azcon-Aguilar, C. 2005. Microbial co-operation in the rhizosphere. J. Exp. Bot. 56: 1761-1778.

Benjamins, R. and Scheres, B. 2008. Auxin: the looping star in plant development. Annu. Rev. Plant Biol. 59:443-465.

Bloemberg, G. V. 2007. Microscopic analysis of plant-bacterium interactions using auto fluorescent proteins. Eur. J. Plant Pathol. 119:301-309.

Bloemberg, G. V. and Lugtenberg, B. J. 2001. Molecular basis of plant growth promotion and biocontrol by rhizobacteria. Curr. Opin. Plant Biol. 4:343-350.

Chenna, R., Sugawara, H., Koike, T., Lopez, R., Gibson, T. J., Higgins, D. G. and Thompson, J. D. 2003. Multiple sequence alignment with the Clustal series of programs. Nucleic Acids Res. 31:3497-3500.

Chernousova, E. Y., Akimov, V. N., Gridneva, E. V., Dubinina, G. A. and Grabovich, M. Y. 2008. Phylogenetic in situ/ex situ analysis of a sulfur mat microbial community from a thermal sulfide spring in the north Caucasus. Microbiology 77:219223.

Cho, K. M., Hong, S. Y., Lee, S. M., Kim, Y. H., Kahng, G. G., Lim, Y. P., Kim, H. and Yun, H. D. 2007. Endophytic bacterial communities in ginseng and their antifungal activity against pathogens. Microb. Ecol. 54: 341-351.

Choi, O., Kim, J., Ryu, C. and Park, C. S. 2004. Colonization and population changes of a biocontrol agent, Paenibacillus polymyxa E681, in seeds and roots. Plant Pathol. J. 20:97-102.

Compant, S., Reiter, B., Sessitsch, A., Nowak, J., Clement, C. and Ait Barka, E. 2005. Endophytic colonization of Vitis vinifera L. by plant growth-promoting bacterium Burkholderia sp. 
strain PsJN. Appl. Environ. Microbiol. 71:1685-1693.

Coutinho, T. A. and Venter, S. N. 2009. Pantoea ananatis: an unconventional plant pathogen. Mol. Plant Pathol. 10:325335.

Da Costa, M., Bach, L., Landrieu, I., Bellec, Y., Catrice, O., Brown, S., De Veylder, L., Lippens, G., Inze, D. and Faure, J. D. 2006. Arabidopsis PASTICCINO2 is an antiphosphatase involved in regulation of cyclin-dependent kinase A. Plant Cell 18:1426-1437.

Dobereiner, J., Urquiaga, S. and Boddey, R. M. 1995. Alternatives for nitrogen nutrition of crops in tropical agriculture. Fertilizer Res. 42:339-346.

Domenech, J., Reddy, M. S., Kloepper, J. W., Ramos, B. and Gutierrez-Mañero, J. 2006. Combined application of the biological product LS213 with Bacillus, Pseudomonas or Chryseobacterium for growth promotion and biological control of soil-borne diseases in pepper and tomato. Biocontrol 51:245258.

Dubnau, D. 1999. DNA uptake in bacteria. Annu. Rev. Microbiol. 53:217-244.

Enya, J., Shinohara, H., Yoshida, S., Tsukiboshi, T., Negishi, H., Suyama, K. and Tsushima, S. 2007. Culturable leaf-associated bacteria on tomato plants and their potential as biological control agents. Microb. Ecol. 53:524-536.

Halda-Alija, L. 2003. Identification of indole-3-acetic acid producing freshwater wetland rhizosphere bacteria associated with Juncus effusus L. Can. J. Microbiol. 49:781-787.

Hedden, P. and Kamiya, Y. 1997. Gibberellin Biosynthesis: enzymes, genes and their regulation. Annu. Rev. Plant Physiol. Plant Mol. Biol. 48:431-460.

Herrero, M., Quiros, C., Garcia, L. A. and Diaz, M. 2006. Use of flow cytometry to follow the physiological states of microorganisms in cider fermentation processes. Appl. Environ. Microbiol. 72:6725-6733.

Joo, G. J., Kim, Y. M., Kim, J. T., Rhee, I. K., Kim, J. H. and Lee, I. J. 2005. Gibberellins-producing rhizobacteria increase endogenous gibberellins content and promote growth of red peppers. J. Microbiol. 43:510-515.

Joo, G. J., Kim, Y. M., Lee, I. J., Song, K. S. and Rhee, I. K. 2004. Growth promotion of red pepper plug seedlings and the production of gibberellins by Bacillus cereus, Bacillus macroides and Bacillus pumilus. Biotechnol. Lett. 26:487-491.

Kang, S. H., Cho, H. S., Cheong, H., Ryu, C. M., Kim, J. F. and Park, S. H. 2007. Two bacterial entophytes eliciting both plant growth promotion and plant defense on pepper Capsicum annuum L. J. Microbiol. Biotechnol. 17:96-103.

Kim, H. J., Lee, J. H., Kang, B. R., Rong, X., McSpadden Gardener, B. B., Ji, H. J., Park, C. S. and Kim, Y. C. 2012. Draft genome sequence of Pantoea ananatis B1-9, a nonpathogenic plant growth-promoting bacterium. J. Bacteriol. 194:729.

Kim, J. W., Choi, O. H., Kang, J. H., Ryu, C. M., Jeong, M. J., Kim, J. W. and Park, C. S. 1998. Tracing of some root colonizing Pseudomonas in the rhizosphere using lux Gene introduced bacteria. Plant Pathol. J. 14:13-18.

Kim, W. I., Cho, W. K., Kim, S. N., Chu, H., Ryu, K. Y., Yun, J. C. and Park, C. S. 2011. Genetic diversity of cultivable plant growth-promoting rhizobacteria in Korea. J. Microbiol. Biotechnol. 21:777-790.

Kloepper, J. W. 1995. Plant growth-promoting rhizobacteria (other systems). In: Azospirillum/plant Associations, Y. Okon, ed. CRC Press, Boca Raton. pp. 137-166.

Kloepper, J. W., Zablotowicz, R. M., Tipping, E. M. and Lifshitz, R. 1991. Plant growth promotion mediated by bacterial rhizosphere colonizers. In The Rhizosphere and Plant Growth, D. L. Keister and P. B. Cregan ed. Kluwer Academic Publishers, Dordrecht, The Netherlands. pp. 315-326.

Lambertsen, L., Sternberg, C. and Molin, S. 2004. Mini-Tn7 transposons for site-specific tagging of bacteria with fluorescent proteins. Environ. Microbiol. 6:726-732.

Lucas García, J. A., Probanza, A., Ramos, B., Ruiz Palomino, M. and Gutiérrez Mañero, F. J. 2004. Effect of inoculation of Bacillus licheniformis on tomato and pepper. Agronomie 24: 169-176.

Martin, R. M., Leonhardt, H. and Cardoso, M. C. 2005. DNA labeling in living cells. Cytometry A 67:45-52.

Morohoshi, T., Nakamura, Y., Yamazaki, G., Ishida, A., Kato, N. and Ikeda, T. 2007. The plant pathogen Pantoea ananatis produces $\mathrm{N}$-acylhomoserine lactone and causes center rot disease of onion by quorum sensing. J. Bacteriol. 189:8333-8338.

Ping, L. and Boland, W. 2004. Signals from the underground: bacterial volatiles promote growth in Arabidopsis. Trends Plant Sci. 9:263-266.

Poonguzhali, S., Madhaiyan, M., Yim, W. J., Kim, K. A. and Sa, T. M. 2008. Colonization pattern of plant root and leaf surfaces visualized by use of green-fluorescent-marked strain of Methylobacterium suomiense and its persistence in rhizosphere. Appl. Microbiol. Biotechnol. 78:1033-1043.

Prieto, P. and Mercado-Blanco, J. 2008. Endophytic colonization of olive roots by the biocontrol strain Pseudomonas fluorescens PICF7. FEMS Microbiol. Ecol. 64:297-306.

Rijavec, T., Lapanje, A., Dermastia, M. and Rupnik, M. 2007. Isolation of bacterial endophytes from germinated maize kernels. Can. J. Microbiol. 53:802-808.

Ryan, R. P., Germaine, K., Franks, A., Ryan, D. J. and Dowling, D. N. 2008. Bacterial endophytes: recent developments and applications. FEMS Microbiol. Lett. 278:1-9.

Ryu, C. M., Farag, M. A., Hu, C. H., Reddy, M. S., Kloepper, J. W. and Pare, P. W. 2004. Bacterial volatiles induce systemic resistance in Arabidopsis. Plant Physiol. 134:1017-1026.

Ryu, C. M., Farag, M. A., Hu, C. H., Reddy, M. S., Wei, H. X., Pare, P. W. and Kloepper, J. W. 2003. Bacterial volatiles promote growth in Arabidopsis. Proc. Natl. Acad. Sci. U. S. A. 100:4927-4932.

Sawabe, T., Fukui, Y. and Stabb, E. V. 2006. Simple conjugation and outgrowth procedures for tagging vibrios with GFP, and factors affecting the stable expression of the gfp tag. Lett. Appl. Microbiol. 43:514-522.

Singh, M. K., Kushwaha, C. and Singh, R. K. 2009. Studies on endophytic colonization ability of two upland rice endophytes, Rhizobium sp. and Burkholderia sp. using green fluorescent protein reporter. Curr. Microbiol. 59:240-243.

Staley, T. E., Lawrence, E. G. and Drahos, D. J. 1997. Variable 
specificity of Tn7::lacZY insertion into the chromosome of root-colonizing Pseudomonas putida strains. Mol. Ecol. 6:8587.

Steenhoudt, O. and Vanderleyden, J. 2000. Azospirillum, a freeliving nitrogen-fixing bacterium closely associated with grasses: genetic, biochemical and ecological aspects. FEMS Microbiol. Rev. 24:487-506.

Taghavi, S., Garafola, C., Monchy, S., Newman, L., Hoffman, A., Weyens, N., Barac, T., Vangronsveld, J. and van der Lelie, D. 2009. Genome survey and characterization of endophytic bacteria exhibiting a beneficial effect on growth and development of poplar trees. Appl. Environ. Microbiol. 75:748-757.

Tamura, K., Dudley, J., Nei, M. and Kumar, S. 2007. MEGA4: Molecular Evolutionary Genetics Analysis MEGA. software version 4.0. Mol. Biol. Evol. 24:1596-1599.

Thomas, P., Kumari, S., Swarna, G. K. and Gowda, T. K. 2007. Papaya shoot tip associated endophytic bacteria isolated from in vitro cultures and host-endophyte interaction in vitro and in vivo. Can. J. Microbiol. 53:380-390.

Thomashow, L. S. 1996. Biological control of plant root pathogens. Curr. Opin. Biotechnol. 7:343-347.

Toth, I. K., Bel, K. S., Holeva, M. C. and Birch, P. R. J. 2003. Soft rot erwiniae: From genes to genomes. Mol. Plant Pathol. 4:
$17-30$.

Ugoji, E. O., Laing, M. D. and Hunter, C. H. 2005. Colonization of Bacillus spp. on seeds and in plant rhizoplane. J. Environ. Biol. 26:459-466.

Walker, T. S., Bais, H. P., Grotewold, E. and Vivanco, J. M. 2003. Root exudation and rhizosphere biology. Plant Physiol. 132: 44-51.

Watanabe, K. and Sato, M. 1999. Gut colonization by an ice nucleation active bacterium, Erwinia Pantoea ananas reduces the cold hardiness of mulberry pyralid larvae. Cryobiology 38: 281-289.

Weyens, N., van der Lelie, D., Taghavi, S., Newman, L. and Vangronsveld, J. 2009. Exploiting plant-microbe partnerships to improve biomass production and remediation. Trends Biotechnol. 27:591-598.

Wielbo, J. and Skorupska, A. 2001. Construction of improved vectors and cassettes containing gus $\mathrm{A}$ and antibiotic resistance genes for studies of transcriptional activity and bacterial localization. J. Microbiol. Methods 45:197-205.

Wirth, R., Friesenegger, A. and Fiedler, S. 1989. Transformation of various species of gram-negative bacteria belonging to 11 different genera by electroporation. Mol. Gen. Genet. 216: 175-177. 